\title{
Synergy: an old wisdom, a new paradigm for pharmacotherapy
}

\author{
Maique Weber Biavatti*
}

\author{
Pharmaceutical Sciences Department, Center for Health Sciences, Federal University of Santa Catarina
}

\begin{abstract}
Synergy is one of the governing principles of the natural world, and is one of the reasons for the increasing complexity of the evolutionary process. Broadly speaking, it relates to the cooperative effects produced by the interaction between various forces, elements, parts or individuals in a given context. Since the last century, some clinical studies have described the increased efficiency of a combination of drugs. To study the effects of the drug interactions, the most commonly cited model is that of Loewe, and the classical graphical representation is the iso-effect curve (isobologram). Plants contain an enormous diversity of specialized micromolecules, therefore there is a high likelihood of interactions between them. Through recent synergy studies, various synergistic interactions have been demonstrated among extracts of different plants, and between components of the same extract.
\end{abstract}

Uniterms: Natural extracts. Synergy. Phytotherapeutics.

Sinergia é um dos princípios que rege o mundo natural, apontado como uma das razões para a crescente complexidade do processo evolutivo. De uma forma ampla, ela se refere aos efeitos cooperativos produzidos pela interação entre diversas forças, elementos, partes ou indivíduos em um dado contexto. Desde o ultimo século, alguns estudos clínicos tem descrito a eficiência ampliada da combinação de fármacos. Para estudar os efeitos da interação de fármacos, o modelo mais citado é o da aditividade de Loewe, e também a representação clássica é o isobolograma, ou curva iso-efeito. As plantas contem uma diversidade enorme de micromoléculas especializadas, e consequentemente, alta probabilidade de interações entre elas. Através de estudos recentes dos efeitos sinérgicos, varias interações sinérgicas estão sendo demonstradas entre extratos de diferentes plantas e também entre componentes de um mesmo extrato.

Unitermos: Extratos naturais. Sinergia. Fitoterápicos.

\section{INTRODUCTION}

Synergy is one of the governing principles of the natural world. It is not only an effect that is ubiquitous in nature, but is also considered the reason for the growing complexity of the evolutionary process. Broadly speaking, synergy is defined as the combined or cumulative effects produced by interactions between various forces, particles, elements, substances, parts or individuals in a given context. It is derived from the Greek synergos, working together, or literally, cooperating. Synergy is often associated with the clichê "the whole is greater than the sum of the parts", an idea which emerged at the time of Aristotle (350 AC), and is described in his work Metaphysics. But

*Correspondence: M. W. Biavatti. Laboratório de Farmacognosia, Departamento de Ciências Farmacêuticas, Centro de Ciências da Saúde, Universidade Federal de Santa Catarina - UFSC, Campus Universitário/Trindade, 88040-900 Florianopolis - SC, Brasil. E-mail: maique@ccs.ufsc.br synergy is not always greater than the sum of the parts, in some cases, the synergic result is merely different. Another mistaken idea is that synergy always produces positive or beneficial effects, which is not always the case.

In pharmacology, since the last century, the medical clinic has been aware of the benefits of combining drugs. It is observed that isolated medical substances with action in just one molecular target are, in general, less effective for treating a disease than a therapy with combined medical substances, which act on various targets simultaneously (multi-target), potentializing the therapeutic effect. Over the last 10 years, classical medicine has gradually abandoned therapies with a single substance (monotherapy), in favor of treatments with a combination of drugs (multitherapy), like the now well-established treatments for AIDS, cancer, malaria, hypertension and infections. Another shift in paradigm that has been taking place recently is multitherapy focused on the activation of mechanisms which 
protect and repair the organism, rather than destroying the agents which cause the damage (Csermely, Agoston, Pongor, 2005).

Multi-drug therapy (multi-target, multitherapy) is more effective and less vulnerable to adaptive resistance because the biological systems are less able to compensate the action of two or more substances simultaneously. As a result, mono-target drugs are incapable of effectively combating complex pathological conditions like cancer and infectious diseases (Keith, Zimmermann, 2004).

The strategy used today for the development of many drugs is based on the premise that the drug acts in a central molecular target of a given mechanism, which involves identifying and validating individual targets and their chemical modulators (micromolecules) or biological modulators (macromolecules, such as antibodies). The development of this process can take decades of investment and study, with a very low success rate. The understanding that acting on a single target is in most cases, insufficient to restore the balance in a biological system, has led to the search for new drugs that act on multiple targets, to maximize (or potentialize) the therapeutic effect. Thus, the principle of synergy becomes a major contemporary challenge in the discovery of new therapeutic agents (Lehar et al., 2007). Zimmermann, Lehar and Keith (2007) cite current examples of multi-target therapies. However, the effects of combinations of substances, whose result was different and not predictable based on the effects of the isolated substances, was observed and quantified in 1928 (Loewe, 1928). Since then, the concepts of synergy, antagonism and additivism have been extensively explored in pharmacology and toxicology.

In the majority of cases, the synergic combinations are established based on clinical experience, where the drugs already have previously known action for a certain pathology. Considering, therefore, that a mixture can have synergic effect in a certain target, even without presenting initial activity in isolation, the mathematical combination of a previous library can greatly increase the therapeutic arsenal of previously-described drugs. For example, a collection of 1000 substances (drugs or OTC or GRAS) gives access to around 500,000 pairs of combinations. Furthermore, the variations in the molar proportion and liberation sequence of the drugs are also important, and spatially increase the scope of the research. In a study on synergy in fungicides, 30 drugs were investigated, combined in pairs, of which nine are correctly used as fungicides and 21 are used for other indications. The 435 possible combinations of the 30 drugs would produce 22 synergic combinations, of which none were like known fungicide agents, six had combinations between fungicide and non-fungicide, and 16 had combinations between two non-fungicide drugs (Borisy et al., 2003).

In the search for synergic drug combinations, mathematical analyses and refined statistics have been developed and revised by various researchers (Barrera et al., 2005; Berenbaum, 1989; Greco, Bravo, Parsons, 1995). Some methods provide only a qualitative conclusion (Loewe activity and the classic isobologram), while others also provide a quantitative measure of the intensity of the interaction, such as the response surface method. These differences are due to the mathematical and statistical rigor applied to each one, some methods can be carried out manually (isobologram) while others require a computer (response surface method). In the same way, some use parametric models and others emphasize non-parametric models.

The most widely used and cited model is that of Loewe additivity, which is the most commonly used to determine the interaction with various types of experiments, and the most common graphic representation is through the isobologram (iso-effect curve).

An isobologram is constructed by outlining on the $x$ and $y$ axes the inhibitory doses of two agents, for a given effect. If the effect is additive, the totaled doses are proportional to the effect, which is verified by a shift towards the straight line on the graph, which connects two doses with equal effects, a linear isobol, when the agents are not synergic. When the curve of the isobol moves towards the origin (concave line) this indicates that the agents in the mixture are synergic, and when the opposite occurs (convex line) they present antagonism. In other words, the same biological effects of the agents in isolation is obtained at lower (or higher) doses of the mixture (Figure 1).

\section{SYNERGY AND PHYTOTHERAPEUTICS}

It is known that plants contain a wide diversity of specialized micromolecules (secondary metabolites), and this diversity presupposes a high likelihood of interactions.

The therapeutic indications of medicinal plant-based extracts are, in most cases, empirical, and practitioners of phytotherapy intuitively believe that $a$ total extract acts better than an equivalent dose of an isolated substance (Nelson, Kursar, 1999). Through synergy studies, it is now possible to prove the validity of this sentence, with some recent works confirming the presence of interactions and amplified effect in different plant extracts, and also between components of the same extract, as exemplified in Table I.

Like western phytotherapy, oriental systems like Traditional Chinese Medicine and Indian Medicine - 


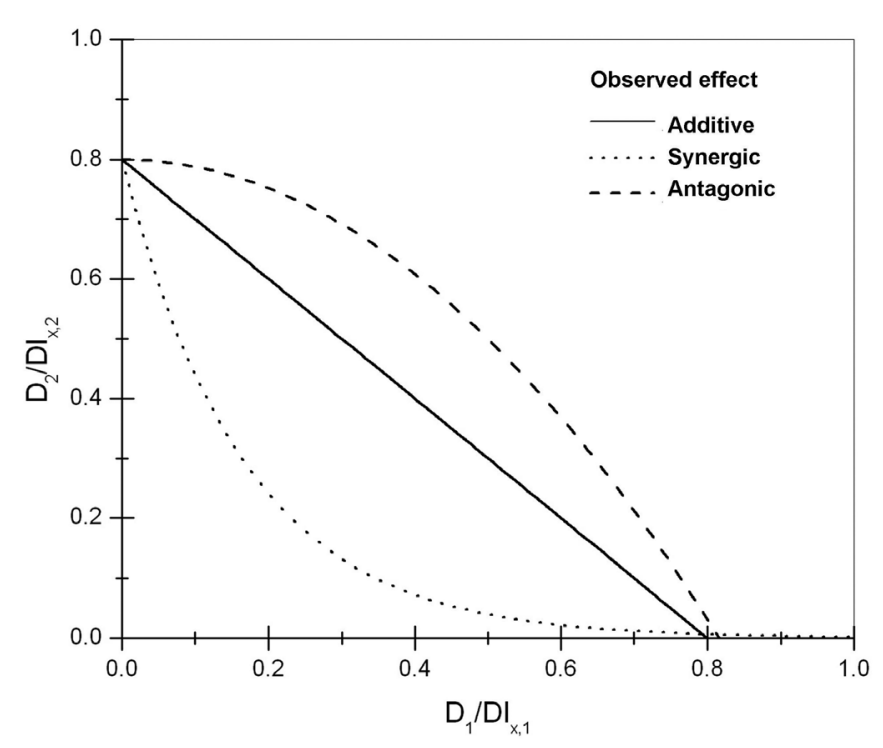

FIGURE 1 - Generic example of an iso-effect curve isobologram, which demonstrates the presence of synergy or antagonism between two therapeutic agents. $\mathrm{X}$ and $\mathrm{Y}$ axes: ratio between the dose of combined agents 1 and 2 to the dose of 1 and 2 in isolation, for the same biological effect.

Ayurveda - consider synergy an intrinsic part of their philosophy. Combined plants and medicinal extracts are common, and are found throughout history. They are developed by empirical observation and formulated for each individual, according to their particular characteristics. In phytotherapy, there are potentially significant advantages associated with the interaction within and between extracts: (1) increased efficiency, (2) reduction of undesirable effects, (3) increase in stability or bioavailability of the free agents, and (4) obtaining an adequate therapeutic effect with relatively small doses, when compared with a synthetic medication (Inui et al., 2007).

The substances that constitute a total extract may be academically divided into: active substances, co-effectors and matrix formers, and the interaction between them can protect the active substances from decomposition. This may be one of the reasons why Ayurveda medicine, one of the most ancient systems of medicine, incorporates into many of its specific formulas a combination of black pepper (Piper longum) and ginger (Zinziber officinalis). Black pepper contains the alkaloid piperine (1), which increases the bioavailability of various drugs (Williamson, 2001).

Determining the pharmacological mechanism of action of a plant extract is not an easy task, due mainly to the high degree of interactions and the diversity of their thousands of components. Often a predominant mechanism may be potentialized by lesser mechanisms. This fact, besides producing a more favorable response than just one isolated constituent, enables different therapeutic responses to the same substances to be determined, depending on the other substances in the matrix. For example, the flavonoid isoorientin (2) is an active component in extracts of different plants, such as in Gentiana olivieri, which is traditionally used as a hypoglycemiant (Sezik et al., 2005), and is also described as an active component of Passiflora incarnata, which is a plant with reputed sedative and calming properties (Soulimani et al., 1997).

Based on this premise, the sense of seeking to isolate an active principle to discover the mode of action of a certain extract is questionable. Systemic thought suggests that it would be more significant to track and evaluate carefully prepared plant extracts, to search for their mode of action. In fact, what is normally seen when a biomonitored phytochemical fractioning is carried out, is the loss of biological activity as the extract is being fractionated, which often leads the researcher to believe that the extract is devoid of biological activity (Ulrich-Merzenich et al., 2007).

Some studies have also verified the existence of a toxic or undesirable effect when a majority component of the extract is tested in isolation. For example, coumarin (1,2-benzopyrone) is described as the main component in the extract guaco (Mikania glomerata, M. laevigata), which is traditionally used to treat asthma, bronchitis and other complaints of the respiratory tract. This isolated component has proven anticoagulant action, but in general, no complaints are observed from users of guaco extract in relation to blood coagulation disorders. In a study in mice, extravasation of red blood cells of the pulmonary tissue was observed in animals treated with coumarin, which did not occur in the group treated with guaco extract (Santos et al., 2006)

The geographic location of the medicinal plants (as well as seasonality) can influence the production of marker substances of an extract. Extracts of Brazilian Orchid Tree (Bauhinia forficata) produced with leaves collected in the same period of the year, but from geographically different locations, presented different contents for their main marker, the flavonoid glycosilated campferitrin. Abundant in one extract and practically non-existent in another, this leads one to suppose that there is a difference in the pharmacological activity or in the quality of the extracts. However, quantifying the total flavonoids in both extracts, very similar total values are observed, which leads us to imagine that there is an internal compensation in the production of the flavonoids by the plant, for environmental reasons, notwithstanding the expected pharmacological activity (Pinheiro et al., 2006).

The emerging microarray technology, which is a large-scale analysis technique, enables the simultaneous 
TABLE I - Plant extracts with evidence of synergic/polyvalent activity

\begin{tabular}{|c|c|c|c|}
\hline Species & Majority constituents & Effects & Indications/uses \\
\hline $\begin{array}{l}\text { Hypericum } \\
\text { Hypericum perforatum }\end{array}$ & $\begin{array}{l}\text { Hypericins, hyperforin, xanthones, } \\
\text { flavonoids, procyanidins }\end{array}$ & $\begin{array}{l}\text { Inhibition of monoamine recapture; } \\
\text { inhibition of MAO and COMT } \\
\text { Procyanidin increases bioavailability } \\
\text { of hypericin }\end{array}$ & Mild antidepressant \\
\hline $\begin{array}{l}\text { Kava-kava } \\
\text { Piper methysticum }\end{array}$ & $\begin{array}{l}\text { Kavapyrones: Yangonin, demethoxy- } \\
\text { yangonin, dihydromethisticin }\end{array}$ & $\begin{array}{l}\mathrm{GABA}_{\mathrm{A}} \text { facilitation; Inhibition of } \\
\text { sodium and calcium canals; inhibition } \\
\text { of NE recapture. Increase the } \\
\text { bioavailability of the others }\end{array}$ & $\begin{array}{l}\text { Ansiolytic, sedative, anticonvulsant, } \\
\text { antispasmolytic, antiinflammatory }\end{array}$ \\
\hline $\begin{array}{l}\text { Valerian } \\
\text { V. officinalis } \\
\end{array}$ & $\begin{array}{l}\text { Valtrate, isovaltrate, valerenone, } \\
\text { valerenic acid }\end{array}$ & Multiple GABA mechanisms & Insomnia and sedative \\
\hline $\begin{array}{l}\text { Urtiga } \\
\text { Urtica dioica (leaves) }\end{array}$ & $\begin{array}{l}\text { Oxylipin (13-hydroxyoctadecadienoic } \\
\text { acic), derivatives of caffeic acid }\end{array}$ & $\begin{array}{l}\text { Inhibition of cyclooxygenase and } \\
\text { cytosine }\end{array}$ & Arthritis and rheumatoid arthritis \\
\hline $\begin{array}{l}\text { Devil's claw } \\
\text { Harpagophytum procumbens; } \\
\text { H. zeyheri }\end{array}$ & Harpagoside & $\begin{array}{l}\text { The components of the total extract } \\
\text { cause stronger inhibition of the } \\
\text { biosynthesis of the leukotriene } \\
\text { and thromboxane than the isolated } \\
\text { harpagoside }\end{array}$ & Antiinflammatory and analgesic \\
\hline $\begin{array}{l}\text { Liquorice } \\
\text { Glycyrrhiza glabra }\end{array}$ & Glycyrrhizin and isoliquiritin & $\begin{array}{l}\text { The extract increases the action of the } \\
\text { hydrocortisone }\end{array}$ & Antiinflammatory and anti-cough \\
\hline $\begin{array}{l}\text { Marijuana } \\
\text { Cannabis sativa }\end{array}$ & $\begin{array}{l}\text { Tetrahydrocanabinol (THC) e } \\
\text { canabidiol (CBD) }\end{array}$ & $\begin{array}{l}\text { THC has muscle relaxing, analgesics } \\
\text { and appetite stimulating effects; CBD } \\
\text { increases the antispasmodic activity }\end{array}$ & Antispasmodic, aperient \\
\hline $\begin{array}{l}\text { Hawthorn } \\
\text { Crataegus oxyacantha }\end{array}$ & $\begin{array}{l}\text { Procyanidins, flavonoids-C- } \\
\text { glycosylates }\end{array}$ & $\begin{array}{l}\text { Inhibitor of the angiotensin converter } \\
\text { enzyme; endothelin dependant relaxing } \\
\text { effect of the smooth muscle }\end{array}$ & Cardiotonic \\
\hline
\end{tabular}

evaluation of thousands of parameters in a single experiment (for better understanding, see http://www.bio.davidson.edu/Courses/genomics/chip/chip.html). It is particularly effective for giving a general overview in the search for standards of gene expression in biological samples. Through the determination of the expression of thousand of genes simultaneously, the promising technology enables researchers to compare the molecular behavior of various types of cell strain and different tissues, when exposed to a determined pathological or experimental condition. The application of this technique in the study of plant extracts has proven the multi-target principle (Mischiati et al., 2006; Ulrich-Merzenich et al., 2007), i.e. there is in fact a synergic interaction between the various components of an extract. For example, in a recent work which used this technique, the profiles of genetic responsiveness to the estrogen of two soy extracts were compared with the two corresponding isolated phytoestrogens. The gene expression obtained for the extracts was comparable to that of the isolated phytoestrogens, and $10 \mathrm{mM}$ of daidzein isoflavone (3) correlated with the profile of the soy extracts, where the estimated daidzein concentration is around 100 times lower (Ise et al., 2005).

In this sense, one of the first published examples of synergy in phytotherapeutics was observed in Ginkgo biloba. Its pharmacological activity can be seen through 
in vitro tests of platelet aggregation. Ginkgolides (4) are known to be FAP antagonists, which is one of the mechanisms of antiinflammatory action. A mixture of ginkgolides A, B and C at a dose of 100-240 mg can generate a FAP-antagonist effect in humans, however, a dose of $120 \mathrm{mg}$ of extract of standardized Ginkgo, which contains only 6-7 mg of ginkgolides, produces an equivalent effect. As in the previous example, this means there are other substances that act at different levels, through other mechanisms, potentializing the effect of the isolated substance (Williamson, 2001).

Various works have been published on synergism and antimicrobial activity of plant extracts and their components, such as Berberis freemontii and its alkaloid berberine (5), whose activity is potentialized by the addition of two constituents of the plant, flavonolignan 5 '-methoxyhydrocarpine $\mathrm{D}(6)$ and porphryn pheophorbide $a$ (7) in strains of Staphylococcus aureus. Although these substances potentialize the effects of a sub-therapeutic concentration of the alkaloid, none of them have antibiotic activity per se (Kinghorn, 2001).

Extracts of spices like oregano (Origanum vulgare) and mulberry (Vaccinium macrocarpon) present a combined antimicrobial effect potentialized against Vibrio parahaemolyticus, an effect which is even more marked in the presence of lactic acid, suggesting that these may be viable alternatives for extending the preservation time of foods (Lin; Labbe; Shetty, 2005). The same extracts combined were also active and synergic against Helicobacter pylori, and the author suggests managing this bacteria with a diet containing these juices (Vattem et al., 2005).

Another study which combines extracts of Salvia chamelaeagnea and Leonotis leonurus observed synergy when tested against Gram-positive bacteria (Bacillus cereus and Staphylococcus aureus); however, antagonism was verified when the extracts were tested in Gram-negative bacterias (Escherichia coli and Klebsiella pneumoniae) (Kamatou et al., 2006).

A synergic effect has also been cited in the literature against extracts with high antioxidant potential (which exert capture of free radicals, due to the high quantity of polyphenolic substances) and antibiotics, and the authors suggest that the extracts may be used to increase the clinical effectiveness of antibiotics, or reduce their doses and prevent adverse effects. This was observed for the methanol extracts of Cordia gilletii and tetracycline in strains of Staphylococcus aureus which are resistant to methicillin (Okusa et al., 2007). The same effect was verified for 15 different plant extracts, including extract of Camellia sinensis (tea plant), Lawsonia inermis (henna), Mangifera indica (leaves of mango tree) and Punica granatum (pomegranate), which also demonstrate a synergic effect with tetracycline against Escherichia coli (ESbL-02) (Ahmad; Aqil, 2007). The flavone baicalin (8) is an important active constituent of the species Scutellaria baicalensis, used in Chinese medicine, which potentialized the effectiveness of both penicillin and ethanol extract of Notopterygium in strains of Staphylococcus aureus (Meng et al., 2006). Another researcher has the same opinion in relation to the isolated polyphenol epigallocatechin gallate and amphotericin B (Han, 2007). This synergic effect described by various authors demonstrates that the extracts are probably acting in different cell targets of the antibiotics.

Other studies have observed various forms of synergy in cytotoxic and antitumoral activity of extracts, as in juice of pomegranate (Punica granatum), which presented antiproliferative activity in various strains of tumor cells, when compared with their isolated polyphenols (Seeram et al., 2005). Similarly, in another study, it was observed that the combination of four extracts significantly increased the antitumor activity, compared with the extracts in isolation (Adams et al., 2006).

Also, ethanol extract of the mushroom Phellinus igniarius presented synergic effect when combined with the chemotherapeutics Oxa (oxaliplatina) or 5-FU (5-Fluorouracil) (Song et al., 2008), and the natural flavolignan silibinin (9) showed synergy with the chemotherapeutics cisplatin and doxorubicin (Scambia et al., 1996).

A series of new studies has emerged in this area, and some traditional phytotherapeutics have now their mode of synergic action verified and their effectiveness scientifically proven - modern rational phytotherapy exemplified in Table I.

An example of clinically investigated synergy to indicate the effectiveness of combinations of medicinal extracts is the association of valerian (Valeriana officinalis) with kava-kava (Piper methysticum), which proved to be better for the treatment of insomnia induced by stress than each of the extracts in isolation, like kavakava associated with passion fruit (Passiflora incarnata), which demonstrated a potentialized sedative hypnotic effect. Likewise, ginseng (Panax ginseng) associated with ginkgo (Ginkgo biloba) proved to be more effective in improving cognitive function than the isolated form, as measured by the performance in carrying out various arithmetic tasks (Williamson, 2001; Wagner, 2006). The central nervous system consists of an immense network of synaptic interactions, whose standard of functioning is eminently synergic. Hoasca is an indigenous term which defines an hallucinogenic fermented drink that has been used since ancient times, in the Orinoco and Amazonas 
river basins for ceremonial and medicinal purposes, and has sacramental significance for indigenous peoples in the region (Peru, Bolivia, Ecuador, Brazil). This drink consists of a decoction of Banisteriopsis caapi (woody lian) and Psychotria viridis (leaves), and it is also known as ayahuasca, caapi, daime, yagé etc. The drink is consumed every one or two weeks in a ceremonial context, and can present some tolerance, but does not cause physical or psychological dependence. Although other plants are included in the drink, scientific investigations have shown that the common denominator is the presence of the $\beta$-carboline alkaloids of the harmala type, particularly harmine (10), harmaline (11), tetrahydroharmine (THH) (12) and $N, N$-dimethylltryptamine (DMT) (13), which is considered responsible for the hallucinogenic effects. The amines THH and DMT increase the concentration of serotonin (5-HT) (14), the first through the inhibition of serotonin reuptake in the pre-synaptic sites and the second through the binding in serotonergic sites in the brain, facilitating new perceptions. However both are degraded by MAO-A (monoamino oxidase - type A) when administrated orally. This degradation does not occur in the case of the drink Hoasca, due to the presence of the alkaloids harmina and harmaline, which promote a synergic effect between the alkaloids, because they are specific and reversible inhibitors of MAO-A (IMAO-A), enabling the arrival of psychoactive agents (THH and DMT) in the brain (Figure 2) (Callaway et al., 1999).

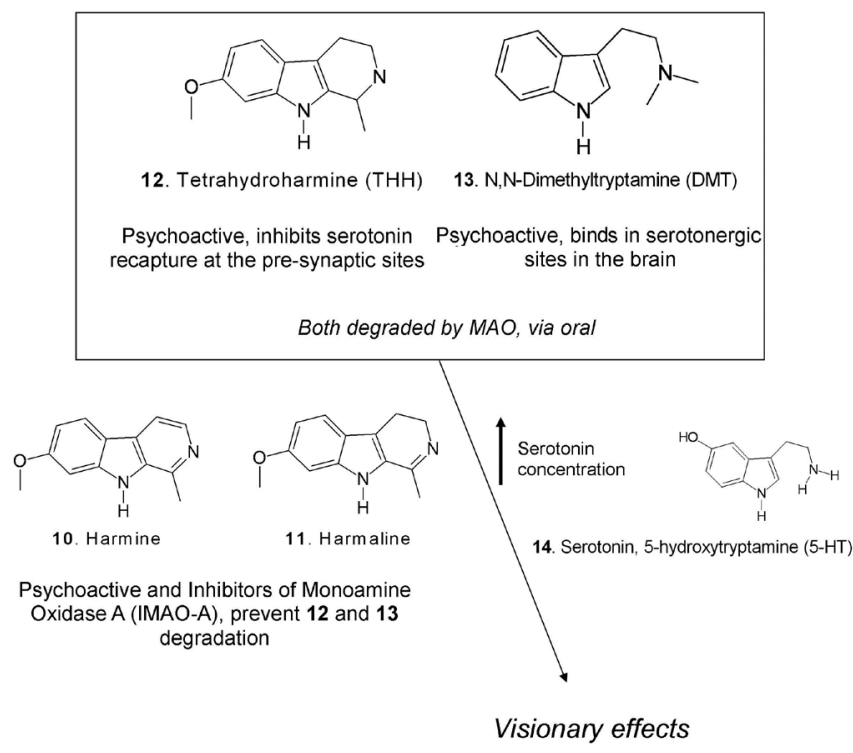

FIGURE 2 - Synergic mechanism of the psychoactive alkaloids found in the drink Hoasca.

To conclude, the study of synergy is an emerging field in all aspects, and there is much to be developed and
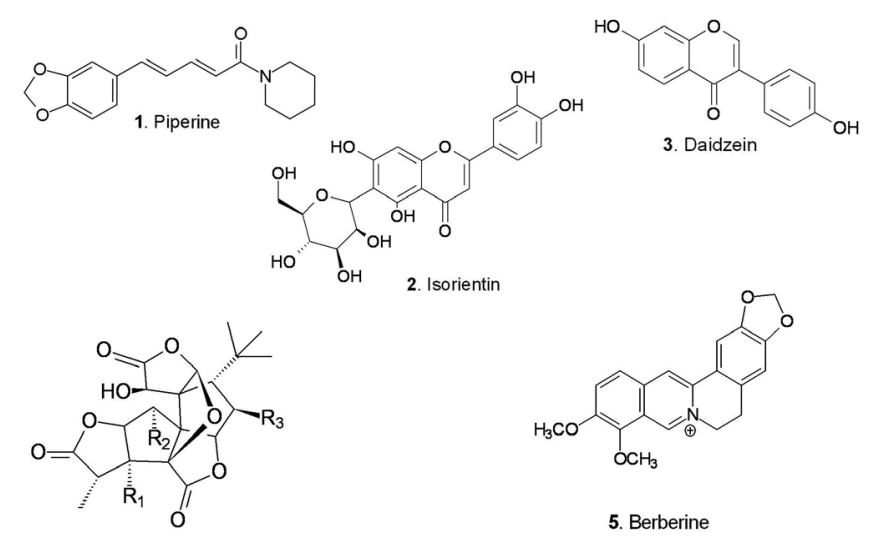

4a. Ginkgolide $A, R_{1}=R_{2}=H, R_{3}=O H$ 4b. Ginkgolide $B, R_{1}=R_{3}=O H, R_{2}=H$ 4c. Ginkgolide $C, R_{1}=R_{2}=R_{3}=O H$

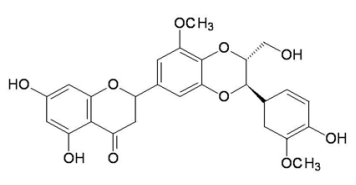

6. 5'-Methoxyhydrocarpine D

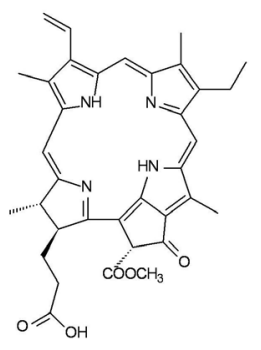

7. Pheophorbide a
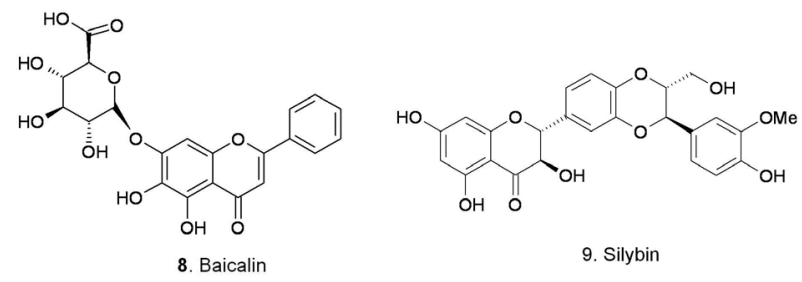

FIGURE 3 - Some natural bioactive compounds cited in the text.

understood in all areas of knowledge. New technological tools that enable the mechanisms of action of combined natural extracts or synthetic agents to be tracked will enable the creation and corroboration of differentiated medical therapies, increasing the quality of existing health treatments.

\section{REFERENCES}

ADAMS, L. S.; SEERAM, N.P.; HARDY, M.L.; CARPENTER, C.; HEBER, D. Analysis of the interactions of botanical extract combinations against the viability of prostate cancer cell lines. Evid. Based Complement. Alternat. Med. (eCAM), v.3, p.117-124, 2006.

AHMAD, I.; AQIL, F. In vitro efficacy of bioactive extracts of 15 medicinal plants against ESbL-producing multidrugresistant enteric bacteria. Microbiol. Res., v.162, p.264-275, 2007. 
BARRERA, N.P.; MORALES, B.; TORRES, S.; VILLALON, M. Principles: Mechanisms and modeling of synergism in cellular responses. Trends Pharmacol. Sci., v.26, p.526$532,2005$.

BERENBAUM, M. C. What is synergy? Pharmacol. Rev., v.41, p.93-141, 1985.

BORISY, A.A.; ELLIOTT, P.J.; HURST, N.W.; LEE, M.S.; LEHAR, J.; PRICE, E.R.; SERBEDZIJ,G.; ZIMMERMANN, G.R.; FOLEY, M.A.; STOCKWELL, B.R.; KEITH, C.T. Systematic discovery of multicomponent therapeutics PNAS, v.100, p.7977-7982, 2003.

CALLAWAY, J. C.; MCKENNA, D. J.; GROB, C. S.; BRITO, G. S.; RAYMON, L. P.; POLAND, R. E.; ANDRADE, E. N.; ANDRADE, E. O.; MASH, D. C. Pharmacokinetics of Hoasca in healthy humans. J. Ethnopharmacol., v.65, p.243-256, 1999.

CSERMELY, P.; AGOSTON, V.; PONGOR, S. The efficiency of multi-target drugs: the network approach might help drug design. Trends Pharmacol. Sci., v.26, p.178-182, 2005.

GRECO, W. R.; BRAVO, G.; PARSONS, J. C. The search for synergy: a critical review from a response surface perspective. Pharmacol. Rev., v.47, p.331-385, 1995.

HAN, Y. Synergic anticandidal effect of epigallocatechin- $O$ gallate combined with amphotericin B in a Murine model of disseminated Candidiasis and its anticandidal mechanism. Biol. Pharm. Bull., v.30, p.1693-1696, 2007.

INUI, T.; WANG, Y.; DENG, S.; SMITH, D.C.; FRANZBLAU, S.G.; PAULI, G. F. Counter-current chromatography based analysis of synergy in an anti-tuberculosis ethnobotanical. J. Chromatogr. A, v.1151, p.211-215, 2007.

ISE, R.; HAN, D.; TAKAHASHI, Y.; TERASAKA, S.; INOUE, A.; TANJI, M.; KIYAMA, R. Expression profiling of the estrogen responsive genes in response to phytoestrogens using a customized DNA microarray. FEBS Lett., v.579, p.1732-1740, 2005.

KAMATOU, G. P. P.; VILJOEN, A. M.; VAN VUUREN, S.F.; VAN ZYL, R.L. In vitro evidence of antimicrobial synergy between Salvia chamelaeagnea and Leonotis leonurus. S. Afr. J. Bot., v.72, p.634-636, 2006.
KEITH, C.T.; ZIMMERMANN, G. R. Multi-target lead discovery for networked systems. Curr. Drug Discov., v.?, p.19-23, 2004.

KINGHORN, A. D. Pharmacognosy in the $21^{\text {st }}$ century. $J$. Pharm. Pharmacol., v.53, p.135-148, 2001.

LEHAR, J.; ZIMMERMANN, G. R.; KRUEGER, A.S.; MOLNAR, R.A.; LEDELL, J.T.; HEILBUT, A.M.; SHORT III, G.F.; GIUSTI, L.C.; NOLAN, G.P.; MAGID, OA.; LEE, M.S.; BORISY, A.A.; STOCKWELL, B.R.; KEITH, C.T. Chemical combination effects predict connectivity in biological systems. Mol. Syst. Biol., v.3, p.1-14, 2007.

LIN, Y. T.; LABBE, R. G.; SHETTY, K. Inhibition of Vibrio parahaemolyticus in seafood systems using oregano and cranberry phytochemical synergies and lactic acid. Innov. Food Sci. Emerg. Technol., v.6, p.453-458, 2005.

LOEWE, S. Die Quantitation Probleme der Pharmakologie. Ergeb. Physiol. Biol. Chem. Exp. Pharmakol., v.27, p.47187, 1928.

MENG, Z.; SOP, C.; XUEFU, Y.; DONGMING, X.; WEI, W.; LIJUN, D. Characteristics of Baicalin Synergy with Penicillin or Notopterygium Ethanol Extracts Against Staphylococcus aureus. Tsinghua Sci. Technol., v. 11, p. 459-461, 2006.

MISCHIATI, C.; SERENI, A.; KHAN, M. T. H.; LAMPRONTI I.; GAMBARI, R. Effects of plant extracts on gene expression profiling: from macroarrays to microarray technology. Adv. Phytomed., v.2, p.21-33, 2006.

NELSON A. C.; KURSAR, T. A. Interactions among plant defense compounds: a method for analysis. Chemoecology, v.9, p.81-92, 1999.

OKUSA, P. N.; PENGE, O.; DEVLEESCHOUWER, M.; DUEZA, P. Direct and indirect antimicrobial effects and antioxidant activity of Cordia gilletii De Wild (Boraginaceae). J. Ethnopharmacol., v.112, p.476-481, 2007.

PINHEIRO, T. S.; JOHANSSON, L. A.; PIZZOLATTI, M. G.; BIAVATTI, M. W. Comparative assessment of kaempferitrin from medicinal extracts of Bauhinia forficata Link. J. Pharm. Biomed. Anal., v.41, p.431-436, 2006. 
SANTOS, S. C.; KRUEGER, C. L.; STEIL, A. A.; KREUGER, M. R.; BIAVATTI, M. W.; WISNIEWSKI JUNIOR, A. LC characterisation of guaco medicinal extracts, Mikania laevigata and M. glomerata, and their effects on allergic pneumonitis. Planta Med., v.72, p.679-684, 2006.

SCAMBIA, G.; DE VINCENZO, R.; RANELLETTI, F. O.; PANICI, B.; FERRANDINA, G.; AGOSTINO, G. D.; FATTOROSSI, A.; BOMBARDELLI, E.; MANCUSO, S. Antiproliferative Effect of Silybin on Gynaecological Malignancies: Synergism with Cisplatin and Doxorubicin. Eur. J. Cancer, v.32a, p.877-882, 1996.

SEERAM, N. P.; ADAMS, L. S.; HENNING, S. M.; NIU, Y.; ZHANG, Y.; NAIR, M. G.; HEBER, D.; NAVINDRA, P. In vitro antiproliferative, apoptotic and antioxidant activities of punicalagin, ellagic acid and a total pomegranate tannin extract are enhanced in combination with other polyphenols as found in pomegranate juice. J. Nutr. Biochem., v.16, p.360-367, 2005.

SEZIK, E.; ASLAN, M.; YESILADA, E.; ITO, S. Hypoglycaemic activity of Gentiana olivieri and isolation of the active constituent through bioassay-directed fractionation techniques. Life Sci., v. 76, v. 11, p. 1223-1228, 2005.

SONG, T. Y.; LIN, H. C.; YANG, N. C.; HU, M. L. Antiproliferative and antimetastatic effects of the ethanolic extract of Phellinus igniarius (Linnearus: Fries) Quelet. $J$. Ethnopharmacol., v.115, p.50-56, 2008.
SOULIMANI, R.; YOUNOS, C.; JARMOUNI, S.; BOUSTA, D.; MISSLIN, R.; MORTIER, F. Behavioural effects of Passiflora incarnata $\mathrm{L}$. and its indole alkaloid and flavonoid derivatives and maltol in the mouse. J. Ethnopharmacol., v.57, p.11-20, 1997.

ULRICH-MERZENICH, U.; ZEITLER, H.; JOBST, D.; PANEK, D.; VETTER, H.; WAGNER, H. Application of the "-Omic-" technologies in phytomedicine. Phytomedicine, v.14, p.70-82, 2007.

VATTEM, D. A.; LIN, Y.-T.; GHAEDI, R.; SHETTY, $\mathrm{K}$. Cranberry synergies for dietary management of Helicobacter pylori infections. Process Biochem., v.40, p.1583-1592, 2005.

WAGNER, H. Multitarget therapy - The future of treatment for more than just functional dyspepsia. Phytomedicine, v.13, p.122-129, 2006.

WILLIAMSON, E. M. Synergy and other interactions in phytomedicines. Phytomedicine, v.8, p.401-408, 2001.

ZIMMERMANN, G.R.; LEHAR, J.; KEITH, C.T. Multi-target therapeutics: when the whole is greater than the sum of the parts. Drug Discov. Today, v.12, p.34-42, 2007.

Received for publication on $09^{\text {th }}$ July 2008 Accepted for publication on $25^{\text {th }}$ March 2009 